\title{
The Regionalism Paradox in the Fight against Human Trafficking: Indonesia and the Limits of Regional Cooperation in ASEAN
}

\author{
Nur Iman Subono \\ Universitas Indonesia \\ Meidi Kosandi \\ Universitas Indonesia
}

This paper examines the role of regional cooperation in the Association of Southeast Asian Nations (ASEAN) in the fight against human trafficking for Indonesia. ASEAN members have been collectively active in responding transnational security issues with series of talks and collaboration agreements since early 2000s. Lately in 2015, ASEAN agreed on ASEAN Convention against Trafficking in Persons, particularly Women and Children (ACTIP) that requires each member to collaborate in information sharing and providing effective safeguard and protection of victims. Yet, the frequency of human trafficking crime occurrence remains high and tend to increase in Indonesia in 2017-2018. The objective of this paper is to examine the effectiveness and success of ACTIP implementation in the fight against human trafficking in Indonesia. Based on two years research (2017-2018) in three provinces with the largest number of victims in Indonesia, this paper shows the tendency of persisting crime despite the implementation of regional and national anti-trafficking policies. The research was conducted by archive study, literature study, discourse analysis, and depth interviews with local government officials, police, prosecutors, victims, and traffickers. This paper argues that the relative success of ASEAN in establishing convention at the high-level meetings has not been followed with the success in its implementation in the society. Three main factors have contributed to the ineffectiveness of the agreements, i.e. (1) ASEAN institutional arrangement as a collection of sovereign states instead of supranational organization with binding authority; (2) the lack of commitment of ASEAN sovereign member-states to the agreements; and (3) the complexity and variety of the nature of the crime in each member-state. In effect, these factors have contributed in generating the regionalism paradox in ASEAN where states tend to revert to national policies instead of seeking regional collective solution.

\section{INTRODUCTION}

ASEAN countries share the same problemof human trafficking in the region and increase of awareness of the importance of collective action to the collective problem, including for Indonesia as one of the countries with most victims of trafficking crime. However, despite increasing concerns on human trafficking among ASEAN countries and improving achievements in regional cooperation to the crime, the number of victims and criminal cases remains high in ASEAN countries, including Indonesia. This leads us to question the efficacy of ASEAN regional cooperation on the combat against human 
trafficking. This paper questions whether or not Indonesia benefits from the regional cooperation in antitrafficking policy in ASEAN and elaborates the factors behind it and implications.

ASEAN has been active in arranging regional cooperation in fighting human trafficking as a crime against humanity. The collective concern over human trafficking can be found as early as 2004, in the ASEAN Declaration against Trafficking in Persons, Particularly Women and Children. The latest agreement was in 2015, the ASEAN Convention on Trafficking in Persons, Particularly Women and Children (ACTIP). The signing and ratification of ACTIP supposedly enhanced the effort to fight human trafficking, including increasing cooperation and coordination between member countries in law enforcement, data and information exchange, and protection of victims. The convention is active since 2017 after 6 members ratified it, and Indonesia became the 8th member to ratify it in 2018. This institutional achievement at the regional organization was accompanied by the increase of the number of trafficking cases and victims. In Indonesia, the United Nations International Children's Emergency Fund (UNICEF) estimates 100,000 women and children become victims of trafficking every year (UNICEF, 2018). Based on police report, in 2017 there were 1,451 victims were saved from 123 cases investigated. The number in 2017 is much higher than that reported in 2016, where 332 victims were rescued from 110 cases of trafficking (US Department of State, 2018). The number of victims and cases unfolded by the police tend to be growing as up until April 2018, there were already found 1,154 victims rescued from trafficking operation to Middle East countries (CNN Indonesia, April 23, 2018).

Despite the achievement of the government in tackling human trafficking and the regional cooperation, the picture of human trafficking crime depicted from police reports appears to be dominated by illegal migration (undocumented migrant labor) cases rather than human trafficking. $75 \%$ of the cases are not involving exploitation by the employer of traffickers, whereas the victims voluntarily traveled to the destination countries looking for employment(Subono and Kosandi, 2018). This implies that the majority of the cases resolved by the police and prosecuted by the court were mainly closer to illegal migration problem rather than human trafficking crime. In addition to the data problem from the police report, these cases are only account for less than $0.1 \%$ of the estimated victims of trafficking in Indonesia based on UNICEF report (UNICEF, 2018). These indicate that the transnational organized crime still provides a great challenge for the government. It is important to check whether the regional cooperation in ASEAN can help Indonesia to tackle the crime and prevent it from reoccurring and replicating in the long term and analyze the contributing factors.

This paper is organized into several sections. The second section will discuss theoretical review as basis for understanding ASEAN cooperation in dealing with human trafficking. The third section will discuss the paradox between progress and achievement of regional agreements and domestic combat against trafficking on the one hand, and persisting number of victims annually on the other hand. The fourth part discusses the three factors contributing to the ineffectiveness of ASEAN framework for combating human trafficking, i.e. ASEAN institutional characteristics, commitment to combating against human trafficking, and varying crime characteristics of ASEAN member countries. This paper will then be closed with a concluding section.

\section{THEORETICAL UNDERPINNINGS: ASEAN REGIONALISM}

Many have argued that international and regional cooperation is important for countering human trafficking, considering the nature of the crime as a transnational and organized crime (Kicinger, 2004; Akaha, 2009; andCaballero-Anthony, 2010). As a transnational and organized crime, it would be easier to deal with the trouble to identify and prosecute the traffickers and their criminal organization, with cooperation and coordination between the source and destination countries. Kicinger asserted that international migration and human trafficking are threat to international security in the European Union (EU) and thus responded collectively by the regional organization(Kicinger, 2004). According to

Kicinger, EU countries view international migration generated non-traditional security threat internationally if it is uncontrolled and massive. Thus, the regional response to the problem was then to arrange migration control. The EU signed agreements with third countries, sources of illegal migrants. 
Their policy priority was migration control, accompanied by economic development and technical assistance programs to prevent illegal migration. The regional cooperation in the EU is considered necessary and effective to cope with international security threats such as human trafficking and illegal international migration.

EU relative success in coping with illegal migration and human trafficking does not necessarily means that the same policy will be effective in other regional organizations, especially not in the short term. As Morehouse noted, even among EU members, signing the 2000 UN Anti Trafficking Protocol was difficult(Morehouse, 2009:pp.32-35). Germany signed the Protocol only in 2006 after struggling with debate between international cooperation and sovereignty options. After the protocol was signed, it was in effect immediately with the regional organization tend to expand regional cooperation to increase regional security.

In ASEAN, not too long after the signing of ACTIP in 2015, the minimum number of ratifications to activate the agreement (6 members) was achieved in 2017. Today, 8 members have ratified the convention, including Indonesia since 2018. However, the faster pace of regional response in ASEAN in activating an international/regional agreement does not imply improving effectiveness in fighting human trafficking. The effectiveness of the agreement for helping members to combat against human trafficking has so far been minimum, considering that the trafficking cases remain high in Southeast Asia.

To examine the effectiveness of anti-trafficking policy, there are two main approaches in the studies on human trafficking, i.e. policy oriented and empirical studies. Morehouse (2009) argues for the importance of the comprehensiveness of the policy. Other example of policy oriented studies is the edited volume by Dragiewicz (2015), emphasizing key issues and priorities in antitrafficking policies. Empirical study is by far the dominant literature on the topic. Many in the literature presented data and information on the operation of the crime and the practice of antitrafficking policies and institutions. Three publications can be mentioned as examples, i.e. International Organization for Migration (IOM) study on ASEAN and Trafficking in Persons (David, 2007), Cameron's publication entitled "Trafficking and Related Labour Exploitation in the ASEAN Region" (Cameron, 2007), and Kranrattanasuit's case studies of Cambodia, Thailand and Vietnam (Kranrattanasuit, 2014). Some other studies on the topic are more theoretically oriented, such as from Okubo and Shelley (2011) and Nishikawa (2010) that elaborates human trafficking in ASEAN as non-traditional security issue. Wylie (2016) and Lobasz(2019) analyze the formation of anti-trafficking policies from constructivist perspective. There are also some studies in this category that argue for multidisciplinary approach to study the fight against human trafficking. The examples are Aronowitz (2009), Cameron (2008), Holmes (2010), Palmiotto (2015), Territo and Matteson (2012), and Zheng (2010).

In this paper, we examined the effect of ASEAN regionalism on Indonesia's anti trafficking actions. Our study belongs with the theory guided empirical study, not on the norms construction of the regional policy such as suggested by Wylie (2016) and Lobasz (2019), but rather on the domestic application of the regional policy. From liberal institutional perspective, regional integration benefits the member states and it varies based on the level of integration. The member states participate in a regional integration for the benefits to each, and the level of integration tend to expand to the higher level, or wider aspects of cooperation. Based on Balassa's classification of regional integration levels (Balassa, 1994), the EU falls to economic union category and expected to deepening integration into political union. According to Balassa, there are 6 levels of integration, i.e. (1) preferential trade agreement; (2) free trade agreement; (3) common market; (4) customs union; (5) economic union; and (6) political union(Balassa, 1994). ASEAN, on the other hand, is currently at common market stage, and transitioning toward customs union. Thus, ASEAN is basically two levels below the EU in the integration level.

\section{ASEAN REGIONAL COOPERATION IN COMBATING HUMAN TRAFFICKING}

ASEAN response to global fight against human trafficking has been positive. In terms of agreement documents, there are at least five agreements between ASEAN members regarding anti-trafficking since 2004. The first agreement was ASEAN Declaration against Trafficking in Persons, Particularly Women 
and Children 2004. The declaration came soon after ASEAN signed on ASEAN Community in 2003, which includes ASEAN Political and Security Community. After a year of study on nontraditional and transnational security issue, ASEAN members agreed on promoting joint declaration on combating human trafficking, among other issues.

The second document was the 2007 ASEAN Practitioners Guidelines. The guidelines were a response from ASEAN Criminal Justice to the Trafficking in Persons. Earlier in 2006, ASEAN conducted joint study on human trafficking (David, 2008) in ASEAN countries with the IOM. It became clear that human trafficking is a major security issue in ASEAN. The report by IOM noted that ASEAN is lacking regional cooperation in law enforcement and data sharing. The guidelines agreed on the objective of providing assistance to criminal justice institutions in ASEAN countries in their goal securing justice for victims and ending impunity of traffickers (David, 2008). In the guidelines, ASEAN countries agreed on promoting cooperation in judicial/legal cooperation, protection of victims, mutual legal assistance, and networking.

The third document was the ASEAN Leaders' Joint Statement in Enhancing Cooperation against Trafficking in Persons in 2011. The joint statement emphasized the commitment of ASEAN leaders on combating human trafficking, including protection of victims and prevention policy. The joint statement also expressed the need for ASEAN Convention on Trafficking in Persons and assign the ASEAN Ministerial Meetings on Transnational Crime (AMMTC) to realize the vision.

The fourth document was the ASEAN Convention against Trafficking in Persons. The ACTIP was signed on by ASEAN leaders in the 2015 ASEAN Summit and in effect after minimum 6 signatories ratify it in domestic law in 2017. The convention was finally in effect in 2017 with 6 out of 10 members ratified the regional agreement. Three benefits of the application of ACTIP are: (1) common understanding on the concept of human trafficking for better identification and response; (2) providing framework for cooperation in law enforcement and victims protection at the destination, transit, and/or source countries; (3) providing framework for cooperation in enhancing the capacity of government institutions.

ASEAN Plan of Action to Combat Trafficking in Persons (PAP) was signed in 2017. The objectives of the PAP are to: (1) strengthen the rule of law and border control among member countries; (2) intensify efforts to prosecute cases of trafficking in persons; and (3) strengthen regional cooperation based on shared responsibilities to effectively address demand and supply that fosters all forms of trafficking in persons. The PAP further details the plan toward achieving the goals.

\section{PERSISTING CRIME: ASEAN REGIONAL COOPERATION IN QUESTION}

The above description on the development of ASEAN collective response to human trafficking shows us the positive image, but only on institutional norms. In practice, after the activation of ACTIP in 2017, regional cooperation in law enforcement, victim protection, data sharing, and institutional capacity development, has not been realized in Indonesian combat against human trafficking. US Government report on Trafficking in Persons 2018 still placed Indonesia with other countries at risk of human trafficking in the 'tier 2'(US Department of State, 2018). Indonesia has made significant progress in antitrafficking policy, but still has not coped with some hindrances such as corrupt officials that have made illegal documentation for migration possible and misdirected law enforcement.

The number of human trafficking crime cases and victims in Indonesia tend to be sustained since 2013. The number of cases and victims are presented in Table I. 


\section{TABLE 1 \\ TRAFFICKING CASES IN INDONESIOA 2013-2017}

\begin{tabular}{ccc}
\hline \hline Year & Victims & Cases \\
\hline $\mathbf{2 0 1 3}$ & 427 & 188 \\
$\mathbf{2 0 1 4}$ & 434 & 141 \\
$\mathbf{2 0 1 5}$ & 288 & 103 \\
$\mathbf{2 0 1 6}$ & 332 & 110 \\
$\mathbf{2 0 1 7}$ & 1451 & 123 \\
\hline \hline
\end{tabular}

Source: Subono and Kosandi, 2018

As shown in the Table I, the number of investigated cases every year since 2013 tends to be over 100 cases. The number of victims rescued by the police varied and increase dramatically since 2017. According to IOM report (2018), the number of victims of trafficking in Indonesia in 2005-2017 has reached 8876 people. In 2018, 104 dead bodies were sent home from Middle East as victims of trafficking.

Based on US Government report on Trafficking in Persons in 2018, Indonesia's effort to combat human trafficking has been acknowledged. Indonesia was put in 'tier 2' among the states 'that do not meet the TVPA (Trafficking Victims Protection Act of 2000) standards, but making significant efforts to bring themselves into compliance to those standards" (US Department of State, 2018). In terms of institutional effort, Indonesia has already issued anti-trafficking law since 2007. The Law No. 21 of 2007 on Human Trafficking Eradication regulated that anyone involved in human trafficking by providing transportation, shelter, recruiting, and exploitation is punishable by 3-15 years imprisonment and US\$ 8,000-40,000 fine. In 2009, the government set the National Action Plan on Eradicating Human Trafficking and Child Sexual Exploitation 2009-2014, issued by the Minister of Women Empowerment and Child Protection (Minister Policy No. 25 of 2009).

The National Action Plan was renewed for the following period (2015-2019) to include the formation of the Task Force for Prevention of and Tackling Human Trafficking. Consists of related government institutions such as law enforcement institutions, immigration, and local government, the Task Force is accountable for the following responsibilities:

1. Coordinating prevention and tackling effort against human trafficking

2. Conducting advocation, socialization, training, and cooperation

3. Monitoring the progress of victim protection, including health rehabilitation, social rehabilitation, returning to home town/village, and social reintegration

4. Monitoring the progress of law enforcement

5. Writing reports and evaluation

It is interesting to note from the description above that the number of trafficking victims on the one hand and the progress of anti-trafficking action on the other hand are two contrasting facts. It happens that anti-trafficking policies and efforts have no correlation with human trafficking crime. The progressive institutional arrangement on anti-trafficking appears to have no effect on reducing an preventing the crime.

An investigation at micro level on individual cases of trafficking revealed the dysfunction of the regional cooperation in dealing with human trafficking. In an interview with an NGO activist at the borderland in West Kalimantan on August 25, 2017, the activist explained that cooperation with local government institutions in Malaysia has been difficult so far. Many among the Indonesian victims of trafficking in Malaysia seek help from Indonesian local NGO near the border. Advocacy to help Indonesian migrant workers whose documents and wage were kept by the employers had to be done directly with the employers, without assistance from the Malaysian government, as well as Indonesian. Malaysian police appear to be reluctant to assist Indonesian NGO's advocacy in Malaysia. Indonesian embassy in Malaysia is also often hesitant to request for Malaysian police's cooperation to Indonesian 
NGO's advocacy activities in Malaysia, although the embassy often sends their staffs to accompany the activists in doing advocacy.

The brief description above represents the core problem of this research, namely the paradox, or the contrasting facts between institutional development and the high number of human trafficking victims. If we look at the development of institutional cooperation in ASEAN, we will have a positive impression. But if we look at the practice at the local level, we will have a different picture. Regardless to the development of institutional cooperation, the number of the crime remains high and the collaboration has been difficult to implement.

\section{ASEAN INSTITUTIONAL CHARACTERISTICS: THE ASEAN WAY}

One of the reasons why regional agreement in ASEAN has not yet manifested in combating against human trafficking lies in the institutional characteristics of ASEAN. There are 3 characters of the institution that have affected the nature of regional cooperation in ASEAN. The first characteristic is the non-interference principle. ASEAN has been successful in uniting the states in the region that were formerly conflictual and maintain peace for over 50 years now. When ASEAN was formed, the region was conflictual. Almost all the states were involved in inter-state conflicts. Indonesia was at confrontation policy against Malaysia following its disagreement toward the formation of the Federation of Malaya. Malaysia was also in conflict with Singapore over the latter's independence, and with Thailand and the Philippines over border dispute. Yet, the five founding members (i.e. Indonesia, Malaysia, Thailand, Singapore, and the Philippines) managed to form the organization that eventually unite the whole 10 members in peace, harmony, and sustainable development in 5 decades. The non-interference principle played important role in this matter. The openness of the states toward participating in ASEAN regionalism was partly due to the principle. Joining ASEAN has so far been without surrendering sovereignty.

The principle creates boundaries for the regional cooperation to work within the will of individual member states. States' participation and compliance to any agreement will depend largely on the will of the individual states. ASEAN secretariat and any member state will not enforce any collective decision and interfere with single state's decision. With this principle, ASEAN and any member state cannot force other members to cooperate in law enforcement, information sharing, or protection the victims of human trafficking. The cooperation will have to rely on other member states' will and commitment to act collectively. The non-interference principle is also seen in the application of ACTIP, where the agreement was agreed to be effective only after at least 6 of the signatories ratified the agreement into domestic laws. Despite the agreement and ratification, both Indonesia and Malaysia cannot force collaboration between Indonesia and Malaysia in the fight against trafficking because of the principle of non-interference.

The second characteristic is the function of ASEAN Secretariat as meeting organizer rather than as a supranational body with real power to make decisions and sanction incompliance. In this way, ASEAN has the characteristics of an intergovernmental organization where decisions are made by the member states, not the organization or Secretariat. In the structure of the organization, the summit meeting posed as the top decision maker. The Secretariat is only responsible in administering decision making among state leaders and implementing the decisions. With this institutional character, there is no guarantee that every decision in the ASEAN meetings, especially in countering human trafficking, will be effective. ASEAN Secretariat has no power to monitor and control the implementation of anti-trafficking policies in ASEAN. Combined with the non-interference principle, the two norms generate stronger boundaries to effective counter trafficking.

The third characteristic is the primacy of consensus in decision making. This is the third important norm in ASEAN that has been affecting the decision making mechanism in the organization. ASEAN values mutual respect and tolerance, and this was incorporated in the decision making process in the form of prioritizing consensual decision that every member could agree. In this regard, ASEAN adopted the ASEAN - $\mathrm{X}$ formula in the decision making, so every member can agree to a decision without the 
necessity of implementing it immediately. In this way, ASEAN can keep deepening and widening integration without internal conflict and exclusion.

The strong tendency toward consensus in ASEAN decision making process reduces the importance of punishment and sanction as solution to collective and shared problems, and places the importance of incentive in cooperation. This is a problem when the organization faces problems where there is no incentive in cooperation while at the same time the cost, such as losing sovereignty, is rather high.

The three norms in ASEAN constituted an institutional characteristic which is well known as "the ASEAN way'. These norms have contributed positively to the formation of a regional cooperation organization that promotes peace, cooperation and development in a long time. Nevertheless, it has been difficult to ensure cooperation in law enforcement, data and information sharing, and protection of victims.

\section{MEMBER STATES' COMMITMENT TO REGIONAL COOPERATION IN COMBATING HUMAN TRAFFICKING}

The second factor that has been limiting the benefits of ASEAN cooperation in combating against human trafficking is the member states' commitment to the regional agreement. In the case of Indonesian victims in Malaysia, cooperation in investigation, lawsuit, sharing information and victim protection has been minimum. This lack of cooperation and coordination limits the capacity of both governments to tackle and prevent human trafficking. Each state tends to revert to national policy and actions instead of strengthening cooperation and coordination in combating human trafficking.

Thailand was put into the 'tier 1' list by the US government in their report on Trafficking in Persons published in June 2018(US Department of State, 2018). In the previous year, Thailand was in the 'tier 2 watch list' or two levels lower. It is interesting to note that only in a year Thailand can move from 'tier 2 watch list' into 'tier 1'.Tier 1 list includes 'the governments of countries that fully meet the TVPA's minimum standards for elimination of trafficking".Tier 2 watch list comprises "the governments of countries that do not fully meet the TVPA's minimum standards but are making significant efforts to bring themselves into compliance with those standards, and for which... cannot show evidence of improvement".

What Thailand did over the past years was increasing cooperation with the United States in antitrafficking efforts. In 2013, Thailand was categorized as 'tier 3' country that is "governments that do not fully meet the TVPA's minimum standards and are not making significant efforts to do so". The country was known as source and destination country in human trafficking nexus. Since 2013, Thailand started to increase cooperation with the US in combating human trafficking. In the last 5 years, Thailand have received over 2 million US dollars grant aid for improving anti-trafficking combat, including for institutional capacity building, prosecution, civil society empowerment and victim protection and rehabilitation (Habeahan, 2018). In the report on USAID Thailand Counter Trafficking in Persons 2018, the USAID mentioned that the cooperation adopted 5C strategy to combat the crime, i.e. community engagement, change agents, communication, collaboration and continuity, in their cooperation under USAID Thailand Counter Trafficking in Persons Initiative 2017-2022 (USAID, 2018).

Indonesia and Thailand represent the cases where regional cooperation in ASEAN offers minimum benefit for the combat against trafficking. In Thailand case, in the absence of ASEAN's capacity in assisting Thailand's fight against trafficking, it turned to increasing cooperation with the US instead of relying on regional cooperation within ASEAN framework. In Indonesian case, the absence of ASEAN's capacity and minimum cooperation in practice does not make it turn to the great power for assistance. Rather, Indonesia reverted to national effort with proper assistance from international organizations (IOM and UNDP) for the combat against trafficking, particularly in data collecting, legislation, civil society assistance and social campaign. The commitment to strengthen and utilize regional cooperation in combating human trafficking seems to be weak. 


\section{VARYING CRIME STRUCTURE}

The third factor to limit the regional cooperation for combating human trafficking in ASEAN is varying structure of the crime that affect differing policy agenda between states. Unlike Thailand and Vietnam, where the development of tourism industry is accompanied with growing sex trafficking (Sobel, 2018; and Nguyen, 2018), the structure of human trafficking practices in Indonesia is dominated by forced labor derived from labor migration. The policy agenda is heavy on migration control rather than targeting the transnational organized crime.

In Indonesia, the Task Force for Tackling and Preventing Human Trafficking was formed from related government institutions in the central and local governments. The institutions included in the Task Force in the central government are Coordinating Ministry of Human and Cultural Development, Ministry of Women Empowerment and Child Protection, Ministry of Law and Human Rights (including Immigration), Ministry of Education and Culture, Ministry of Health, National Police, and Ministry of Manpower (National Agency for Migrant Labor Placement and Protection, BNP2TKI). At local level, the Task Force includes the local government (Social Service Department, Women Empowerment and Child Protection Department), local police, local immigration office, and local agency for Migrant Labor Placement and Protection (BP3TKI). Since the formation of the Task Force at the central government in 2008 , it has been regularly meeting and coordinating for tackling and preventing human trafficking in Indonesia. The local Task Force was formed by local governments in 2015-2017 to help mainstreaming anti-trafficking into local policies.

Orientation towards migration control can be seen in the structure of the data on trafficking cases. From the total trafficking cases, $70 \%$ are labor trafficking cases. $10 \%$ were sex trafficking cases, and the rest were child trafficking and internal trafficking for domestic sex industry. Sex trafficking cases in the last two years were growing especially connected to East Asian sex trafficking network, particularly with China.

To Indonesian government, tackling transnational sex trafficking network and protecting victims from trafficking before the crime take place is almost impossible compared to preventing and stopping illegal migration and child trafficking. These types of trafficking are easier to identify and tackle than transnational sex trafficking, especially in the absence of good cooperation and coordination with the destination countries such as East Asian and Middle Eastern countries. Most of illegal migration destined for Malaysia (50\%) and Middle East (45\%) for jobs in primary sectors and as domestic helpers.

This feature of the structure of trafficking in Indonesia requires cooperation and coordination with Malaysia as the main destination country. ASEAN framework for the cooperation and coordination through ACTIP can be an advantage in dealing with human trafficking. However, in the absence of vigorous implementation of the agreement, the biggest challenge for Indonesia is migration control to Malaysia and Middle East. Since 2015, Indonesia has announced moratorium of labor sending to Middle East to reduce the risk of labor trafficking of Indonesian labor. Labor trafficking to Malaysia now has become the largest challenge, and thus migration control as the policy orientation in tackling and preventing trafficking was adopted. In turn, strengthening and utilizing regional cooperation has not yet become high priority in combating human trafficking in Indonesia.

\section{CONCLUSION: REGIONALISM PARADOX IN ASEAN}

The question of efficacy of ASEAN's framework for cooperation and coordination in fighting against human trafficking as addressed in this paper seems to be finely represented by the term paradox. The establishment of ACTIP in 2015 and ratification by 8 members, more than enough to declare that the convention is in effect, represent the positive development that builds expectation of progressive combat against human trafficking in the region. However, persisting crime of human trafficking in the region and the tendency to revert to national policies among ASEAN states, shows that the institutional progress seems to be meaningless to the members as it was not utilized in the national antitrafficking efforts. As if that the cooperation framework was created just to keep ASEAN alive rather than to combat trafficking. 
In this paper, we argue that three factors contributed to the paradox. First, ASEAN as a unique institutional character that is well known as the 'ASEAN way'. Second, the commitment of ASEAN member states toward strengthening and utilizing ASEAN framework for cooperation and coordination in the fight against human trafficking is low. And third, the challenge of trafficking in each country differs from others that states tend to revert to national policies rather than cooperate.

ASEAN framework for cooperation in combating human trafficking is promising. Various aspects of cooperation and coordination has been discussed, agreed, and regulated -despite unbinding. Based on our analysis presented above, if the three contributing factors are changed for the better, the framework for cooperation in ASEAN might just worked out for combating human trafficking in ASEAN.

\section{REFERENCES}

Akaha, T. (2009). Human security in East Asia: embracing global norms through regional cooperation in human trafficking, labor migration, and HIV/AIDS. Journal of Human Security, 5(2).

Aronowitz, A.A. (2009). Human trafficking, human misery: the global trade in human beings. Wesport, Connecticut: Praeger.

Balassa, B. (1994). The theory of economic integration, in The European Union. London: Springer.

Caballero-Anthony, M. (2010, September) Non-traditional security challenges, regional governance, and ASEAN Political and Security Community". Asia Security Policy Initiative Working Paper Series No. 7.

Cameron, S. (2007). Trafficking and related labor exploitation in the ASEAN region. ICSW Briefing Paper.

Cameron, S., \& Newman, E. (eds) (2008). Trafficking in human\$: Social, cultural, and political dimensions. Hong Kong: UN University.

CNN Indonesia (2018, April 23). PolisiUngkap 1154 WNI Korban Perdagangan Orang (The Police Discovered 1,154 Indonesians Victims of Human Trafficking). Retrieved January 26, 2019, from https://www.cnnindonesia.com/nasional/20180423175045-12-292934/polisi-ungkap-1154-wnikorban-perdagangan-orang

David, F. (ed.) (2007). ASEAN and trafficking in persons: Using data as a tool to combat trafficking in persons. IOM and ASEAN.

Dragiewicz, M. (ed.) (2015). Global human trafficking: Critical issues and contexts. London: Routledge.

Habeahan, P.A. (2018). Kerjasama Amerika Serikat dan Thailand dalammenanganaikasus slavery dan human trafficking di industriperikanan Thailand 2013-2017. Journal of International Relations, 4(4), 905-911. Retrieved February 9, 2019, from https://ejournal3.undip.ac.id/index.php/jihi/article/viewFile/22048/20292

Holmes, L. (ed.) (2010). Trafficking and human rights: European and Asia-Pacific perspectives. Cheltenham, UK: Edward Elgar.

IOM. (2018). Counter Trafficking Factsheet. Retrieved from http://www.iom.or.id/sites/default/files/Factsheet\%20-\%20Counter-Trafficking.pdf. Accessed March 4, 2019.

Kicinger, A. (2004). International migration as a non-traditional security threat and the EU responses to the phenomenon. CFMR Working Paper No. 2/2004.

Kranrattanasuit, N. (2014). ASEAN and human trafficking: Case studies of Cambodia, Thailand and Vietnam. Leiden: Brill Nijhoff.

Lobasz, J.K. (2019).Constructing human trafficking: Evangelicals, Feminists, and an unexpected alliance. London: Palgrave Macmillan.

Morehouse, C. (2009).Combating human trafficking: Policy gaps and hidden political agendas in the USA and Germany. VS Research.

Nguyen, T. (2018). Sex Trafficking and the Attribution of Blame: A Comparison between Vietnamese and American Perception of Sex-trafficked Individuals.

Nishikawa, Y. (2010). Human security in Southeast Asia. London: Routledge, 2010. 
Okubo, S., \& Shelley, L. (eds.) (2011). Human security, transnational crime, and human trafficking. London: Routledge.

Palmiotto, M.J. (ed.) (2015). Combating human trafficking: a multidisciplinary approach. Boca Raton: CRC Press.

Sobel, M. (2018). Sex trafficking and the media: Perspectives from Thailand and the United States. London: Routledge.

Subono, I., \& Kosandi, M. (2018). Problems in Combating Human Trafficking: Lessons from Indonesia. Paper presented at International Conference on Research in Behavioral and Social Sciences (ICRBS) 2018, Barcelona, 7-9 December 2018.

Territo, L., \& Matteson, R. (2012). The international trafficking of human organs: a multidisciplinary perspective. Boca Raton: CRC Press.

UNICEF (2018). Factsheet on Sexual Exploitation and Children Trafficking. Retrieved February 17, 2019, from https://www.unicef.org/indonesia/Factsheet_CSEC_trafficking_Indonesia.pdf

US Department of State (2018). Trafficking in Persons 2018.

USAID (2018). USAID Thailand Counter Trafficking in Persons. Retrieved February 9, 2019, from https://www.usaid.gov/sites/default/files/documents/1861/FS_USAID_Thailand_CTIP_May2018 .pdf

Wylie, G. (2016). The international politics of human trafficking. London: Palgrave Macmillan.

Zheng, T. (2010). Sex trafficking, human rights, and social justice. London: Routledge. 